Published in final edited form as:

Pain. 2007 October ; 131(3): 243-257.

\title{
The roles of sodium channels in nociception: implications for mechanisms of pain
}

\author{
Theodore R Cummins ${ }^{1}$, Patrick L Sheets ${ }^{1}$, and Stephen G Waxman $2,3,4$ \\ 1 Department of Pharmacology and Toxicology, Stark Neurosciences Research Institute, Indiana University \\ School of Medicine, Indianapolis, Indiana, 46202
}

2Department of Neurology, Yale University School of Medicine, New Haven, Connecticut, 06510

3 Center for Neuroscience and Regeneration Research, Yale University School of Medicine, New Haven, Connecticut, 06510

4Rehabilitation Research Center, Veterans Administration Connecticut Healthcare System, West Haven Connecticut, 06516

\begin{abstract}
Understanding the role of voltage-gated sodium channels in nociception may provide important insights into pain mechanisms. Voltage-gated sodium channels are critically important for electrogenesis and nerve impulse conduction, and a target for important clinically relevant analgesics such as lidocaine. Furthermore, within the last decade studies have shown that certain sodium channel isoforms are predominantly expressed in peripheral sensory neurons associated with pain sensation, and that the expression and functional properties of voltage-gated sodium channels in peripheral sensory neurons can be dynamically regulated following axonal injury or peripheral inflammation. These data suggest that specific voltage-gated sodium channels may play crucial roles in nociception. Experiments with transgenic mice lines have clearly implicated Nav1.7, Nav1.8 and Nav1.9 in inflammatory, and possibly neuropathic, pain. However the most convincing and perhaps most exciting results regarding the role of voltage-gated sodium channels has come out recently from studies on human inherited disorders of nociception. Point mutations in Nav1.7 have been identified in patients with two distinct autosomal dominant severe chronic pain syndromes.

Electrophysiological experiments indicate that these pain-associated mutations cause small yet significant changes in the gating properties of voltage-gated sodium channels that are likely to contribute substantially to the development of chronic pain. Equally exciting, a recent study has indicated that recessive mutations in Nav1.7 that eliminate functional current can result in an apparent complete, and possibly specific, indifference to pain in humans, suggesting that isoform specific blockers could be very effective in treating pain. In this review we will examine what is known about the roles of voltage-gated sodium channels in nociception.
\end{abstract}

\section{Introduction}

Pain is a serious medical problem. Pain sensations typically originate in peripheral neurons known as nociceptors. These neurons relay information about noxious stimuli from the

Corresponding Author: Theodore Cummins, Ph.D., Department of Pharmacology and Toxicology, Stark Neurosciences Research Institute, Indiana University School of Medicine, 950 West Walnut St., R2 468, Indianapolis, IN, 46202. Tel. (317) 278-9342, Fax (317) 278-5849, E-mail: trcummin@iupui.edu

Publisher's Disclaimer: This is a PDF file of an unedited manuscript that has been accepted for publication. As a service to our customers we are providing this early version of the manuscript. The manuscript will undergo copyediting, typesetting, and review of the resulting proof before it is published in its final citable form. Please note that during the production process errors may be discovered which could affect the content, and all legal disclaimers that apply to the journal pertain. 
periphery to the central nervous system. Increased pain sensations can result from changes in both peripheral and central neurons. One mechanism that can lead to increased pain sensations is altered electrical excitability of neurons. Voltage-gated ion channels play a major role in determining excitability properties of neurons. Over the last 20 years numerous studies have investigated the role of different ion channels in nociception, hyperexcitability and increased pain sensitivity (Matzner and Devor 1994;Baker and Wood 2001). Although changes in ion channels of central nervous system (CNS) neurons are likely to contribute to altered pain sensitivity, the vast majority of studies have focused on ion channels and ionic currents in peripheral sensory neurons. Changes in the activities of many different ion channel subtypes have been identified in various pain models and there is evidence indicating that several different types of ion channels can play important roles in nociception and altered pain sensitivity. The most compelling evidence implicating a specific ion channel in determining pain sensitivity comes from studies of individuals that exhibit what can be characterized as a complete insensitivity to pain (Cox et al. 2006; Ahmad et al., 2007; Goldberg et al. 2007). These studies provide strong evidence that complete loss of function of one specific voltagegated sodium channel, Nav1.7, results in a complete inability to sense pain. This is clearly an extremely exciting and important finding. Several previous lines of evidence have also indicated that Nav1.7 can play crucial roles in nociception. However, studies have shown that several other sodium channel isoforms can also play important roles in modulating the electrical excitability of sensory neurons and pain-related behaviors in animals, and it appears that multiple sodium channel isoforms expressed in nociceptive neurons are important for tuning the firing properties of these cells. This review examines the roles of voltage-gated sodium channels in nociception and pain mechanisms.

\section{Overview of Sensory Neuronal sodium channels}

Voltage-gated sodium channels (VGSC or $\mathrm{Na}_{\mathrm{v}}$ ) are complex transmembrane proteins that allow the rapid influx of sodium that underlies the depolarizing upstroke of action potentials in excitable cells (Catterall 2000;Goldin et al. 2000). VGSCs typically open ("activate") with within a millisecond in response to membrane depolarizations, often leading to a regenerative all-or-none depolarization typical of action potentials in neurons. VGSCs typically do not remain open for extended periods of time during depolarizations. Current through VGSCs can be terminated within a millisecond or so by a process that can be referred to as fast-inactivation, which is thought to occur when a cytoplasmic loop of the VGSC protein binds within the pore and occludes the flow of sodium ions (West et al. 1992). Recovery from inactivation occurs after the cell membrane potential is repolarized to negative membrane potentials. This allows the channels to return to the resting or closed state, where they are again available to open in response to membrane depolarization (Figure 1). The classic, simplistic view of VGSC activity is that the sole function of the VGSC is to underlie the rapid upstroke of the action potential and that VGSC have three basic conformations or states: closed, open and fast-inactivated.

Although this scheme dominates the classical view of VGSCs, there were early indications that sodium currents are not completely homogeneous. A toxin found in the liver of the puffer fish, tetrodotoxin (TTX), had been identified as a highly selective blocker of CNS and skeletal muscle sodium currents (IC50 5-20 nM; (Ritchie and Rogart 1977)) but a relatively weak blocker of cardiac muscle sodium currents (IC50 1-2 uM; (Baer et al. 1976)), indicating that distinct proteins might generate the sodium currents in different tissues. It was also shown that while CNS neurons seemed to express relatively homogeneous currents exhibiting rapid activation, rapid inactivation and high sensitivity to TTX, dorsal root ganglia (DRG) neurons express more complex currents (Figure 2) that contained both rapid-inactivating TTX-sensitive (TTX-S) components and slowly-inactivating TTX-resistant (TTX-R) components (Kostyuk et al. 1981). It was proposed that the slower TTX-R currents might serve to prolong the duration of the action potential, possibly modulating neurotransmitter release at the nerve terminals. 
With the advent of patch-clamp recording technology (Hamill et al. 1981) it also became clear that TTX-S sodium currents in most, if not all, neurons could exhibit multiple kinetic components. Persistent ("non-inactivating") sodium current components have been identified in CNS neurons (Crill 1996) and in DRG neurons (Baker and Bostock 1997;Cummins and Waxman 1997) and these currents can have significant influences on the threshold for generation of the action potential. However it was not until the molecular biological advances of the late 1980s allowed the identification and cloning of individual sodium channel isoforms that the full complexity of VGSC and sodium currents could be adequately investigated.

The primary functional unit of the voltage-gated sodium channel is a $220-260 \mathrm{kD}$ polypeptide $\alpha$-subunit. Expression of the $\alpha$-subunits is sufficient to obtain functional sodium currents; however, $\beta$-subunits are typically associated with the $\alpha$-subunits (Shah et al. 2000;Isom 2001 ; Yu et al. 2003). Four different $\beta$-subunits have been identified ( $\beta 1, \beta 2, \beta 3$ and $\beta 4$ ). Although initial studies using recombinant subunits expressed in Xenopus oocytes indicated $\beta$-subunits substantially modulated the gating properties of the $\alpha$-subunits, this effect on gating is not as pronounced in mammalian cells (Cummins et al. 2001; Meadows et al. 2002; Chen et al. 2004) and it has been proposed more recently that the $\beta$ subunits may play a role in stabilization of the $\alpha$-subunits in the membrane and/or localization of the $\alpha$-subunits to specific membrane domains (Isom 2001). In addition several other accessory proteins such as calmodulin (Herzog et al. 2003b) or annexin II (Okuse et al. 2002) that have been identified may be important modulators of VGSCs. In this review we focus on the $\alpha$-subunits. Nine distinct voltage-gated sodium channel $\alpha$-subunits (Nav1.1-1.9) have been cloned from mammals (Goldin et al. 2000). A putative tenth sodium channel, NaX, significantly diverges from all of the channels in the Nav1 family (Goldin et al. 2000) and several lines of evidence indicate $\mathrm{NaX}$ is a sodium-gated, not voltage-gated, channel (Akopian et al. 1997; Hiyama et al. 2002). The role of $\mathrm{NaX}$ in neuronal excitability is not known and will not be addressed in this review. Many of the Nav1 $\alpha$-subunits have specific developmental, tissue or cellular distributions (Felts et al. 1997; Trimmer and Rhodes 2004). Nav1.4 is almost exclusively expressed in skeletal muscle (Trimmer et al. 1989). Although Nav1.5 is predominantly expressed in cardiac muscle (Rogart et al. 1989), Nav1.5 message and current is detectable in neonatal DRG and DRG neurons (Renganathan et al. 2002). Nav1.5 message is also detectable in some adult DRG neurons but expression is considered to be very low under most conditions. While mature muscle typically expresses one VGSC isoform, mature neurons typically express multiple sodium channel isoforms. Adult CNS neurons may express combinations of Nav1.1, Nav1.2 and Nav1.6 (Trimmer and Rhodes 2004). Adult DRG sensory neurons can express combinations of Nav1.1, Nav1.6, Nav1.7 Nav1.8 and Nav1.9 sodium channels (Black et al., 1996;Dib-Hajj et al. 1998;Amaya et al. 2000). Nav1.3 is predominantly expressed in immature neurons and is normally found at very low levels in adult neurons (Beckh et al. 1989). However, under certain conditions Nav1.3 expression is upregulated in adult neurons and this may play a role in altered pain sensations (Waxman et al. 1994;Boucher et al. 2000). Although message for Nav1.2, one of the predominant CNS isoforms, is detectable in adult DRG neurons, expression is considered to be low in these cells under most conditions (Black et al. 1996). In this review we concentrate on what is known about Nav1.1, Nav1.3, Nav1.6, Nav1.7, Nav1.8 and Nav1.9, the most important VGSC in peripheral sensory neurons.

\section{$\mathrm{Na}_{\mathrm{v}} 1.7$ (hNE9 or PN1)}

As mentioned above, recent studies (Cox et al. 2006; Ahmad et al., 2007; Goldberg et al. 2007) indicate Nav1.7 plays a crucial role in our ability to perceive pain sensations. Cox et al. studied several families from Northern Pakistan that contained members with an inability to experience pain. Neurological examinations indicated that while these individuals, age 6 to 12 years old, apparently had never experienced any pain sensations they otherwise appeared normal. Sense of proprioception, touch, warmth and cold were considered normal. Vision and 
hearing were normal. Intelligence was considered normal and, although in-depth testing was not performed, there was no overt evidence of either motor or autonomic dysfunction. Goldberg et al. (2007) tested sweating, tear formation, blood pressure regulation and temperature regulation to assess autonomic function and reported these were normal in patients with complete insensitivity to pain. In all three studies the individuals were reported to have a profound, and largely selective, inability to sense pain. The only noted exceptions to this were deficits in olfaction in some patients (Goldberg et al., 2007) and awkward gait in others (Cox et al., 2006). However, these exceptions were not noted in all individuals with the complete insensitivity to pain. It was determined that the pain insensitivity was congenital and could be mapped as an autosomal-recessive trait linked to a region of chromosome 2 that contains the gene SCN9A, which encodes the voltage-gated sodium channel Nav1.7. Sequence analysis of SCN9A found several distinct homozygous nonsense mutations in the affected individuals of each of the three families. In experiments using mutated recombinant Nav1.7 channels it was demonstrated that each of the mutations identified in the three different families eliminated functional Nav1.7 currents in heterologous expression systems. Family members who were heterozygous for the SCN9A mutations, and therefore should have one functional SCN9A allele, reported normal pain phenotypes. Goldberg et al. (2007) identified Nav1.7 truncating mutations in patients with congenital indifference to pain from seven different countries, demonstrating loss-of-function of Nav1.7 can result in an insensitivity to pain in multiple populations. As individuals that lack functional Nav1.7 channels can appear normal except for their complete insensitivity to pain, it was proposed by Cox et al.,Goldberg et al. and Ahmad et al. that drugs that selectively target Nav1.7 might be ideal analgesics.

The $\mathrm{Na}_{\mathrm{v}} 1.7$ subtype is expressed at high levels in rat and human dorsal root ganglia and sympathetic ganglia (Black et al. 1996;Sangameswaran et al. 1997; Toledo-Aral et al. 1997). Elegant in vivo studies using guinea-pigs showed Nav1.7-like immunoreactivity was greatest in cells with C-fiber axons with nociceptive properties (Djouhri et al. 2003). Nav1.7 currents exhibit rapid activation and rapid inactivation from the open configuration (Klugbauer et al. 1995), similar to other TTX-S channels such as Nav1.4 and Nav1.6. However in contrast to Nav1.4 and Nav1.6, which exhibit rapid recovery from fast inactivation, Nav1.7 channels exhibit substantially slower recovery from fast inactivation (Cummins et al. 1998; Herzog et al. 2003a). These data indicate that neurons expressing only Nav1.7 channels would not be capable of firing at high frequencies and this is consistent with studies showing the maximal firing rate of DRG c-fibers is significantly lower than that of A-fibers. Nav1.7 channels also differ from Nav1.4 and Nav1.6 channels in that Nav1.7 takes significantly longer to inactivate at negative membrane potentials (membrane potentials close to the resting membrane potential of neurons). This slower inactivation, which is likely to occur directly from the closed ("resting") configuration, may contribute to the propensity of Nav.7 channels to generate relatively large currents during slow ramp depolarizations (often referred to as ramp currents). Overall the biophysical properties of sodium currents generated by cloned human Nav1.7 channels closely resemble those of the predominant TTX-S current expressed in small diameter DRG sensory neurons (Cummins et al., 1998). Based on these biophysical properties Nav1.7 channels are thought to be important in setting the threshold for generation of action potentials in small diameter nociceptive neurons.

There is now compelling evidence that changes in the gating properties of Nav1.7 can result in increased pain sensations. Studies on families with a painful inherited neuropathy, inherited erythromelalgia (IE, also called primary erythermalgia), support the hypothesis that Nav1.7 is an important determinant of nociceptor excitability. At least 9 distinct point mutations in SCN9A that have been identified in patients with erythromelalgia alter the amino acid sequence of Nav1.7 channels (Yang et al. 2004;Michiels et al. 2005;Drenth et al. 2005;Dib-Hajj et al. 2005; Han et al. 2006; Harty et al. 2006; Lee et al. 2007). These mutations, which are thought to underlie the severe chronic burning pain sensations in the hands and feet that is the primary 
symptom associated with erythromelalgia, all cause significant hyperpolarizing shifts in the voltage dependence of activation (Cummins et al. 2004,Dib-Hajj et al. 2005;Choi et al. 2006 Harty et al. 2006; Han et al. 2006; Sheets et al. 2007). Seven of the eight erythromelalgia mutations that have been characterized to date also produce larger ramp currents and slow the rate at which the channels deactivate (return to the closed and available state from the open state). These alterations in Nav1.7 currents are predicted to contribute to neuronal hyperexcitability and, indeed, DRG neurons transfected with recombinant $\mathrm{Na}_{\mathrm{v}} 1.7$ containing two different erythromelalgia mutations have a lower threshold for firing action potentials and fire at higher-than-normal frequencies in response to suprathreshold stimulation (Dib-Hajj et al. 2005;Harty et al, 2006; Rush et al. 2006a). Interestingly, while some of the erythromelalgia mutations impair slow-inactivation (a slower and mechanistically distinct form of sodium channel inactivation) of Nav1.7 channels, which might be expected to increase neuronal excitability, other mutations enhance slow-inactivation of Nav1.7 channels. Computer simulations of Nav1.7 channels in a sensory neuron model indicates that these divergent effects on slow-inactivation might modulate the degree to which the activation changes caused by specific erythromelalgia mutations increase excitability and therefore could be a factor that modulates the severity of pain symptoms caused by different mutations (Sheets et al., 2007).

Recently, it was discovered that other Nav1.7 point mutations underlie a second autosomal dominant chronic pain disorder, paroxysmal extreme pain disorder (PEPD) (Fertleman et al. 2006). PEPD is characterized by severe burning rectal, ocular, and submandibular pain sensations. Fertleman et al. identified eight distinct Nav1.7 missense mutations in different PEPD families and these mutations are different from those associated with erythromelalgia. Interestingly, the effects on $\mathrm{Na}_{\mathrm{v}} 1.7$ current properties are distinct from those seen with erythromelalgia mutations. The PEPD mutations that have been functionally characterized cause depolarizing shifts in voltage-dependence of steady-state inactivation and cause incomplete inactivation in $\mathrm{Na}_{\mathrm{v}} 1.7$, leading to prolonged persistent currents. Thus while erythromelalgia mutations predominantly enhance activation, PEPD mutations impair inactivation (Figure 3). The differences in the biophysical consequences of the erythromelalgia and PEPD mutations' effects suggest that different patterns of alterations of $\mathrm{Na}_{\mathrm{v}} 1.7$ properties may determine the phenotype of the pain associated with the mutations. These studies on the role of Nav1.7 in erythromelalgia and PEPD show that alterations in Nav1.7 currents are sufficient to cause severe chronic pain in humans.

Autosomal dominant pain disorders are extremely rare and it is not known if specific alterations in Nav1.7 properties are associated with more common pain disorders in humans. In a rat model of painful diabetic neuropathy DRG neurons exhibited larger TTX-S currents and larger ramp current densities (Hong et al. 2004). This was paralleled by increases in both total Nav1.7 protein levels and levels of phosphorylated Nav1.7 protein. However, changes in TTX-R currents were also observed in these DRG neurons as well as increases in levels of phosphorylated Nav1.6 and Nav1.8 protein. Chronic inflammation induces an upregulation in expression of mRNA and protein levels for several VGSCs, including Nav1.7 (Tanaka et al. 1998;Black et al. 2004) indicating that this could be a mechanism contributing to increased pain sensations associated with inflammation. The possible role of Nav1.7 in inflammatory pain is supported by studies showing that localized knock-down of Nav1.7 channels in DRG neurons can reduce inflammatory hyperalgesia. Knockdown of Nav1.7 in the DRG of adult mice via hindpaw application of viruses containing shRNA targeting Nav1.7 reduced inflammatory pain related behaviors (Yeomans et al. 2005). In an elegant transgenic mouse model, Nassar et al. (2004) demonstrated that selectively knocking out Nav1.7 expression in a predominantly nociceptive subpopulation of DRG neurons substantially reduced mechanical and thermal hypersensitivity associated with both acute and inflammatory pain. These animal studies are consistent with the new evidence in humans showing mutations that cause a loss of $\mathrm{Na}_{\mathrm{v}} 1.7$ function underlie the congenital disorder characterized by the inability to experience 
pain (Cox et al. 2006), and that mutations that can cause a gain of Nav1.7 function underlie erythromelalgia and PEPD which are characterized by severe pain.

Patients with IE and PEPD also exhibit exhibit pronounced erythema (abnormal redness and flushing), and it has been suggested that this results from dysfunction of the sympathetic nervous system. Nav1.7 is highly expressed in sympathetic neurons and it has been shown that an IE Nav1.7 mutation that increases excitability in sensory neurons can decrease neuronal excitability when expressed in sympathetic neurons (Rush et al 2006a). Decreased sympathetic activity and increased peripheral release of vasodilating peptides such as calcitonin-gene related peptide from hyperexcitable sensory neurons could both contribute to the observed erythema. It is unclear why the IE mutations predominantly cause pain in the hands and feet or why PEPD mutations predominantly cause rectal and facial pain.

Although there is clear evidence showing that Nav1.7 plays a crucial role in acute pain, pain following inflammation and the chronic burning pain associated with autosomal dominant Nav1.7 channelopathies, it is not clear if Nav1.7 is necessary for all forms of neuropathic pain. In a recent study it was reported that nociceptor specific deletion of Nav1.7 did not eliminate neuropathic pain behavior in mice (Nassar et al. 2005), suggesting $\mathrm{Na}_{\mathrm{v}} 1.7$ may not be important in the production of neuropathic pain. This seems at odds with the observation that humans lacking $\mathrm{Na}_{\mathrm{v}} 1.7$ function have a complete inability to develop pain. However, it is not yet clear if humans that lack Nav1.7 have a complete inability to develop neuropathic pain or if they still have the capacity to eventually develop specific pain disorders, such as painful diabetic neuropathy or cancer-related pain. It is important to note that while humans lacking functional Nav1.7 were generally deemed to be healthy except for the apparently complete lack of ability to experience pain, mice that have a global deficit in Nav1.7 die just after birth (Nassar et al. 2004), suggesting the role(s) of Nav1.7 could be different in mice and humans.

The role of Nav1.7 in other tissues remains unclear. Patients with IE or PEPD have not been reported to show global abnormalities in autonomic function. This, coupled with the lack of apparent autonomic dysfunction in patients lacking functional Nav1.7 channels (Cox et al., 2006; Goldberg et al., 2007) raises the possibility that Nav1.7 activity is not crucial in human sympathetic neurons. The human Nav1.7 was originally cloned from a medullary thyroid carcinoma (hMTC) cell line and was initially proposed to be a neuroendrocrine specific sodium channel (Klugbauer et al., 1995). However, other studies have reported that expression of Nav1.7 is very low or even lacking in endocrine tissue, suggesting Nav1.7 is not important in regulating endocrine function (Toledo-Aral, 1997; Ahmad et al., 2007). However, the possibility has not been ruled out that Nav1.7 expression in sympathetic neurons or other tissues might impact the usefulness of Nav1.7 specific inhibitors in treating pain.

The studies on gain-of-function erythromelalgia and PEPD mutations in Nav1.7 indicate alterations in Nav1.7 can be sufficient to cause chronic pain and the studies on loss-of-function mutations identified in individuals that exhibit an inability to sense pain suggests Nav1.7 is necessary for pain sensations. Although these studies clearly show Nav1.7 plays a crucial role in pain and could possibly be an ideal target for the development of novel analgesics, there is also clear evidence other sodium channel isoforms can also play crucial roles in nociception.

\section{$\mathrm{Na}_{\mathrm{v}} 1.8$ (SNS)}

Nav1.7 clearly plays a crucial role in pain mechanisms, but there is substantial data implicating TTX-R sodium currents and channels in pain. TTX-R sodium currents have been found primarily in the subpopulation of small-diameter sensory neurons thought to be important in nociception (Caffrey et al. 1992; Roy and Narahashi 1992;Elliott and Elliott 1993; Arbuckle and Docherty 1995), suggesting they too may be good targets for the development of novel analgesics. Although it is now known there are two distinct TTX-R sodium channel isoforms 
expressed at high levels in DRG neurons (Nav1.8 and Nav1.9), Nav1.9 currents can be difficult to record in DRG neurons under standard whole-cell recording conditions, and it is likely the TTX-R sodium currents described in the majority of studies are conducted by Nav1.8 channels. Nav1.8 currents, like classic DRG TTX-R currents first described by Kostyuk et al. (1981), display slower rates of activation and fast-inactivation than TTX-S currents. The voltagedependence of steady-state fast inactivation is typically $30-40 \mathrm{mV}$ more depolarized for Nav1.8 currents than for TTX-S currents (Akopian et al. 1996;Sangameswaran et al. 1996), similar to the voltage-dependence of the classic TTX-R current in DRG neurons (Roy and Narahashi, 1992; Cummins and Waxman 1997). The voltage-dependence of activation also tends to be more depolarized for Nav1.8 currents and the classic slowly-inactivating TTX-R DRG sodium current than for TTX-S current. Sodium current recordings from DRG neurons of Nav1.8-null transgenic mice clearly demonstrate that the classic TTX-R currents in DRG neurons are generated by Nav1.8 (Akopian et al. 1999). Because of the depolarized voltage-dependence, Nav1.8 channels are likely to be activated after TTX-S currents in response to stimuli, and thus, in contrast to Nav1.7 currents, Nav1.8 is less likely to contribute to setting the threshold for generation of action potentials in DRG neurons (Rush et al., 2006; Zimmerman et al., 2007). However, studies on DRG neurons from Nav1.8 null mice indicate that Nav1.8 is a major contributor to the upstroke of action potentials in small diameter nociceptive-like DRG neurons (Renganathan et al., 2001). In some neurons, such as those that innervate the cornea, Nav1.8 channels might be both necessary and sufficient for neuronal activity (Brock et al., 1998). The depolarized voltage-dependence of fast-inactivation of Nav1.8 channels also contributes to continuous firing activity during sustained depolarizations in primary sensory neurons (Renganathan et al. 2001). This contribution may be especially important in nerve endings and axons at sites of injury and in other situations where the membrane potential is substantially depolarized.

$\mathrm{Na}_{\mathrm{v}} 1.8$-null mice display decreases in behavioral responses to noxious thermal and mechanical stimulus as well as exhibiting delayed inflammatory hyperalgesia (Akopian et al., 1999). Antisense oligodeoxynucleotides targeted at knocking down Nav1.8 mRNA was also effective at reducing pain-behaviors associated with peripheral inflammation (Khasar et al. 1998;Joshi et al. 2006). These results indicate the $\mathrm{Na}_{\mathrm{v}} 1.8$ channel is important in normal pain function and plays a role in inflammatory pain. TTX-R Nav1.8-like currents are modulated by inflammatory mediators in ways that are likely to contribute to increased excitability of sensory neurons, increasing the rates of activation and inactivation, as well as increasing the magnitude of the current in sensory neurons (Gold et al. 1996;Zhang et al. 2002;Zhang et al. 2006). A number of different molecules have been implicated in modulating Nav1.8 currents, including calmodulin (Choi et al., 2006), contactin (Rush et al. 2005) and protein kinase A (Fitzgerald et al. 1999), although it is not known which of these might contribute to the hyperexcitability associated with different pain disorders.

Nav1.8 channels also appear to be important for the hyperexcitability caused by Nav1.7 erythromelalgia mutations in DRG neurons. The Nav1.7-L858H erythromelalgia mutation increases excitability of DRG neurons, which express Nav1.8 channels, but as shown in Fig. 4 makes sympathetic ganglion neurons, which lack Nav1.8 channels, hypoexcitable (Rush et al, 2006a). This appears to be due to the relatively depolarized inactivation voltage-dependence of Nav1.8 channels, which remain available to open in DRG neurons even when these cells are depolarized by approximately $5 \mathrm{mV}$ by the Nav1.7-L858H mutation. Consistent with this hypothesis, when Nav1.8 channels are co-transfected into sympathetic neurons with Nav1.7$\mathrm{L} 858 \mathrm{H}$, the excitability of the neurons is increased, indicating that the combined activities of Nav1.7 and Nav1.8 channels are important in determining the excitability of peripheral neurons (Figure 4). 
The contribution of Nav1.8 currents to other neuropathic pain conditions remains controversial. Specific knockdown of $\mathrm{Na}_{\mathrm{v}} 1.8$ in rats by intrathecal administration of specific antisense oligodeoxynucleotides was reported to be anti-allodynic and anti-hyperalgesic in response to spinal nerve ligation (SNL) used to mimic neuropathic pain conditions (Lai et al. 2002). While this knockdown is rapidly reversible, it indicates $\mathrm{Na}_{\mathrm{v}} 1.8$ channels play an important role in the onset of neuropathic pain. This observation was intriguing, as several studies have shown that Nav1.8 mRNA, protein and current are substantially decreased in axotomized DRG neurons (Dib-Hajj et al. 1996;Cummins and Waxman 1997;Decosterd et al. 2002). One possibility is that alterations in the activity of Nav1.8 channels in the remaining uninjured neurons are important determinants of hyperexcitability and hyperalgesia associated with injuries that cause neuropathic pain. Gold et al. (2003) proposed that redistribution of $\mathrm{Na}_{\mathrm{v}} 1.8$ channels into the axons of uninjured neurons contributes to the hyperactivity of uninjured neurons; however, it is unclear from this study where the redistributed Nav1.8 channels are coming from. Roza et al. (2003) reported that spontaneous activity in damaged sensory axons was greatly reduced in Nav1.8 null mice compared to wild-type, suggesting Nav1.8 was essential for the development of hyperexcitability following nerve injury. Joshi et al. (2006) reported that Nav1.8 antisense could reduce pain behaviors associated with chronic constrictive nerve injury but not pain behaviors associated with chemotherapy (using the vincristine model) or with skin incisions. Finally, Dong et al. (2007) showed that small interfering RNAs that knock-down Nav1.8 could reverse mechanical allodynia caused by chronic constrictive injury in rats. By contrast, other studies on Nav1.8-null mice have concluded that Nav1.8 does not play any role in neuropathic pain (Kerr et al. 2001;Nassar et al. 2005). It is not entirely clear what accounts for the different observations regarding the role of Nav1.8 in neuropathic pain mechanisms. Upregulation of Nav1.7 expression and TTX-S sodium currents have been documented in Nav1.8-null mice (Akopian et al., 1999) and it has been suggested these changes might compensate for the developmental loss of Nav1.8 channels. However, Nav1.8 current properties are very different from TTX-S current properties, so it is not clear how upregulation of TTX-S channels might completely compensate for loss of Nav1.8. While it is difficult to rule out developmental compensatory mechanisms when using transgenic mice, it can be equally difficult to rule out non-specific effects when using antisense knockdown techniques. Species differences between rats, where the majority of knock-down studies have been carried out, and mice could contribute to the different outcomes.

Specific inhibitors of Nav1.8, which could help address the role of Nav1.8 in different types of pain, have not been available until very recently. A $\mu \mathrm{O}$-conotoxin peptide from marine cone snails (MrVIB) has been recently identified that has a 6-10 fold higher potency at blocking Nav1.8 currents than neuronal TTX-sensitive currents (Ekberg et al. 2006;Bulaj et al. 2006). MrVIB, when infused intrathecally, was effective at reducing neuropathic pain behavior in mice at doses that showed much less severe motor side-effects than lidocaine. A small molecule inhibitor of Nav1.8 channels has also been identified (Jarvis et al. 2007). This molecule, called A-803467, may be unique as it appears to be both a potent and highly selective inhibitor of Nav1.8 channels. It was able to block spontaneous and evoked action potentials in rat sensory neurons and showed efficacy in a wide range of animal pain models, including models of acute mechanical pain, inflammatory pain and neuropathic pain (Jarvis et al. 2007). These studies suggest Nav1.8 selective antagonists could be developed that have better therapeutic indices for treating pain than the currently available nonselective antagonists that target VGSC. Because Nav1.8 is almost exclusively expressed in nociceptive neurons, a selective Nav1.8 channel blocker is likely to be useful in treating inflammatory pain and should be able to provide solid data on the role of Nav1.8 in human neuropathic pain. 


\section{Nav1.9 (NaN, SNS2)}

A second neuronal TTX-R channel, $\mathrm{Na}_{\mathrm{v}} 1.9$ or $\mathrm{NaN}$, has been shown to be preferentially expressed in small-diameter DRG neurons (Dib-Hajj et al. 1998;Tate et al. 1998;Dib-Hajj et al. 1999) and may be predominantly associated with nociceptive neurons (Fang et al. 2002; Fang et al. 2006). Although Nav1.9 was originally cloned almost 10 years ago, it has proven extremely difficult to express and study in heterologous expression systems (Dib-Hajj et al. 2002). Therefore almost all of the data that has been published on Nav1.9 currents has come from studying the native TTX-R currents in DRG neurons. The Nav1.9 current was first identified using Nav1.8-null mice, where the remaining TTX-R current could be readily isolated (Cummins et al. 1999). Characterization of this TTX-R current showed that it activates at potentials close to resting membrane potential $(-60$ to $-70 \mathrm{mV})$ and produces a persistent current (Figure 5B) likely to play a role in setting resting membrane potential as well as contributing to subthreshold eletrogenesis in small DRG neurons (Cummins et al. 1999; Herzog et al. 2001). Nav1.9-null mice have since been developed (Priest et al. 2005;Amaya et al. 2006) and electrophysiological studies on DRG neurons from these mice have confirmed that Nav1.9 does indeed generate the persistent TTX-R current identified by Cummins et al. (2004). One of the reasons that the Nav1.9 current has been difficult to study is because the currents usually disappear very rapidly during recordings of the current (Leffler et al. 2005). Several studies have indicated that Nav1.9 currents are subject to substantial modulation (Cummins et al. 2000;Baker et al. 2003;Coste et al., 2004;Rush and Waxman 2004;Rush et al. 2005) and therefore modulation of Nav1.9 could substantially impact firing thresholds in nociceptive neurons. It has also been proposed (Blum et al. 2002) that Nav1.9 produces current that is activated by brain derived neurotrophin factor (BDNF) and is inhbited by nanomolar concentrations of the neurotoxin saxitoxin. However, this has not been shown in DRG neurons and seems unlikely as the native current in DRG neurons is clearly insensitive to nanomolar concentrations of saxitoxin (Leffler et al., 2005;Priest et al., 2005). While inflammation induces an upregulation of $\mathrm{Na}_{\mathrm{v}} 1.9$ mRNA after 7 days, axotomy cause a down-regulation (Dib-Hajj et al. 1998; Tate et al. 1998), suggesting a role for sensory neuronal hyperexcitability associated with inflammatory pain but not nerve injury induced pain. Indeed, Nav1.9-null transgenic mice show reduced hypersensitivity to inflammatory hyperalgesia induced by formalin, carrageenan, CFA, and prostaglandin $\mathrm{E}_{2}\left(\mathrm{PGE}_{2}\right)$ (Priest et al. 2005) and a reduced sensitivity to specific inflammatory mediators such as bradykinin, serotonin, and ATP while responding normally to nerve growth factor (NGF) (Amaya et al. 2006). By contrast, Nav1.9-null mice do not show altered pain behavior in two different nerve injury models of neuropathic pain (Amaya et al., 2006). These data indicate the $\mathrm{Na}_{\mathrm{v}} 1.9$ channel, along with Nav1.7 and Nav1.8, may be an important contributor to inflammatory pain, but may not be crucial to neuropathic pain associated with nerve injury (Figure 5C,D). Interestingly, although $\mathrm{Na}_{\mathrm{v}} 1.9$ is also expressed in enteric neurons (Rugiero et al. 2003), suggesting that it might play a role in regulating gastrointestinal function, $\mathrm{Na}_{\mathrm{v}} 1$.9-null mice are grossly indistinguishable from wild-type mice and exhibit normal eating behaviors, weight gain and blood chemistry (Priest et al.,

2005; Amaya et al.,2006). $\mathrm{Na}_{\mathrm{v}} 1.9$ may also be expressed in the gonads (Ogata et al., 2000), but $\mathrm{Na}_{\mathrm{v}} 1.9$-null mice have normal fertility so the importance of $\mathrm{Na}_{\mathrm{v}} 1.9$ expression in gonadal tissue is unclear. Further investigation into the specific signaling pathways that can directly modify $\mathrm{Na}_{\mathrm{v}} 1.9$ channels and the pharmacology of Nav1.9 could increase our understanding of the pathophysiology of inflammatory pain and aid the design of novel therapeutics to treat pain caused by inflammation.

\section{Nav1.3}

The role of Nav1.3 channels in pain is controversial. Nav1.3 is a TTX-sensitive channel expressed in developing neurons, but Nav1.3 is significantly down-regulated in mature neurons (Beckh et al. 1989). However, Nav1.3 mRNA and protein are significantly up-regulated 
following axotomy (Waxman et al. 1994;Kim et al. 2002) and inflammation (Black et al. 1999) in rats. These findings led to the proposal that re-expression of Nav1.3 channels might contribute to altered excitability of DRG neurons. Although Nav1.3 currents can exhibit rapid activation and inactivation similar to Nav1.7, Nav1.3 and Nav1.7 current properties are not identical. Recovery from inactivation of Nav1.3 channels (Cummins et al. 2001) can be three times faster than recovery from inactivation of Nav1.7 channels (Cummins et al. 1998). Interestingly, TTX-sensitive sodium currents in axotomized DRG neurons recover from inactivation four times faster than control TTX-S currents (Cummins and Waxman 1997). Increases in recovery rates could facilitate increased firing frequencies and could contribute to increased excitability. Nav1.3 channels are able to generate relatively large ramp currents in response to slow ramp depolarizations (Cummins et al., 2001) and, under some conditions, prominent persistent (or non-inactivating) currents (Chen et al. 2000;Lampert et al. 2006). Increased ramp and persistent currents could reduce the threshold for action potential generation and thus also increase excitability of DRG sensory neurons. Without selective pharmacologic blockers of Nav1.3 channels, it has been difficult to determine how much Nav1.3 channels contribute to the overall sodium current and the neuronal hyperexcitability observed in DRG sensory neurons following nerve injury or inflammation. However, the role Nav1.3 channels in neuronal hyperexcitability and pain behaviors has been investigated using antisense oligodeoxynucleotides (Hains et al. 2003; Hains et al. 2004;Lindia et al. 2005) and Nav1.3 null mutant transgenic mice (Nassar et al. 2006). Hains et al. (2003) found that intrathecally administered Nav1.3 antisense reduced hyperexcitability of dorsal horn neurons and attenuated pain related behavior associated with both spinal cord injury and chronic constrictive injury (CCI) of the peripheral nerve (Hains et al. 2004). By contrast, Lindia et al. (2005) reported that a different Nav1.3 antisense construct did not reduce allodynia associated with nerve injury using the spared nerve injury (SNI) model in rats. Nassar et al. (2006) reported that acute, inflammatory and neuropathic pain behavior is normal in Nav1.3 null mutant transgenic mice. Thus, although the studies by Hains et al. suggest that Nav1.3 expression may modulate pain sensations by increasing the excitability of second order spinal cord neurons, the studies by Lindia et al. and Nassar et al. suggest that Nav1.3 expression may not be necessary for the development of pain behaviors. Without Nav1.3 specific blockers, it may be difficult to definitively determine whether Nav1.3 channels contribute to inflammatory or neuropathic pain sensations in humans. The development of such blockers is thus important from a scientific point of view, although it not clear whether, if available, Nav1.3 selective blockers would be clinically useful.

\section{Nav1.6}

Nav1.6 is a TTX-sensitive VGSC expressed in many different types of neurons. There is strong evidence indicating that Nav1.6 is the predominant VGSC located in the nodes of ranvier in both PNS and CNS myelinated neurons (Caldwell et al. 2000), and transgenic mice in which Nav1.6 has been made non-functional typically die around postnatal day 15 (Garcia et al. 1998), a time at which myelination is rapidly progressing. However, immunocytochemical evidence indicates Nav1.6 is also expressed in unmyelinated peripheral axons (Black et al. 2002). Although Nav1.6 exhibits rapid activation and fast inactivation similar to other TTXsensitive sodium channels, it has some interesting properties. Nav1.6 channels can recover approximately five times faster from inactivation than Nav1.7 channels (Herzog et al. 2003a), suggesting that neurons expressing Nav1.6 channels should be able to sustain higher firing frequencies than neurons expressing Nav1.7 channels. Sodium currents in large DRG neurons, which can fire at relatively high frequencies (Harper and Lawson 1985;Lee et al. 1986), exhibit rapid recovery from inactivation similar to Nav1.6 channels (Everill et al. 2001). Interestingly, this property of Nav1.6 is subject to substantial modulation (Rush et al. 2006b), suggesting firing frequency can be regulated not only by altering sodium channel expression patterns but also by modulating the activity of specific VGSCs. 
Nav1.6 channels are also able to produce resurgent currents in some DRG neurons. Once inactivated, sodium channels do not generally reopen during the repolarization phase of the action potential as the channels recover from inactivation. Thus sodium channels typically transition from the inactivated to the closed state when the membrane potential returns to negative voltages. Resurgent currents are unusual currents that occur during repolarization of the membrane because of channels that are able to reopen. Resurgent currents were first identified in cerebellar Purkinje neurons (Raman and Bean 1997) where they play a crucial role in burst firing of multiple action potentials (Khaliq et al. 2003). Resurgent currents are thought to arise from a distinct inactivation mechanism that involves the $\beta-4$ subunit and phosphorylation (Grieco et al. 2002; Grieco et al. 2005). Although resurgent currents are readily identifiable in Purkinje neurons, they are not recorded from all neurons that express Nav1.6 channels (Raman et al. 1997;Pan and Beam 1999). Recently it was demonstrated that 1) 40\% of large diameter DRG neurons generate TTX-sensitive resurgent currents, 2) that resurgent currents are not observed in DRG neurons isolated from $\mathrm{Na}_{\mathrm{v}}$ 1.6-null mice, and 3) that recombinant Nav1.6 channels can produce large resurgent currents in cultured DRG neurons (Cummins et al. 2005). These data demonstrated that the $\mathrm{Na}_{\mathrm{v}} 1.6$ channel isoform can produce resurgent currents in DRG neurons (Figure 6), and suggested Nav1.1, Nav1.7, Nav1.8 and Nav1.9 currents are unlikely to produce resurgent currents in DRG neurons. However, it is not clear whether resurgent currents are altered by inflammation and/or nerve injury in DRG neurons. The role Nav1.6, if any, in nociception and pain sensations is also not clear.

\section{Nav1.1}

Nav1.1 is a TTX-sensitive VGSC expressed in both CNS and PNS neurons. Nav1.1 has highhomology ( 90\%) with Nav1.2 and Nav1.3 channels. The function of Nav1.1 in sensory neurons is not clear. Nav1.1 currents appear grossly similar to other TTX-sensitive currents, with fast activation and fast inactivation (Smith and Goldin 1998;Lossin et al. 2002). However, characterization of Nav1.1 current properties in sensory neurons is lacking. In situ hybridization studies indicate Nav1.1 mRNA is expressed at highest levels in large diameter sensory neurons, with medium expression in medium diameter neurons and low expression in small diameter neurons (Black et al. 1996), possibly suggesting a limited role in nociceptive neurons. Indeed there are no data implicating Nav1.1 in pain mechanisms. Interestingly, nearly 100 different mutations have been identified in Nav1.1 that are associated with epilepsies (George, Jr. 2005). Although these mutations cause both gain-of-function and loss-of-function of Nav1.1 (George, Jr. 2005), patients with Nav1.1 mutations are not reported to have altered nociception. Recently Nav1.1 mutations associated with migraine have been reported (Dichgans et al. 2005), but it is not known if this is due to alterations in CNS neuronal excitability or trigeminal neuronal excitability. It is not believed that Nav1.1 channels play a special role in nociception and pain.

\section{Nav1.5}

Nav1.5, also referred to as the cardiac sodium channel, is expressed in developing sensory neurons and may be expressed at very low levels in adult DRG neurons (Renganathan et al. 2002). This channel produces unique currents, with relatively hyperpolarized voltage dependencies of activation and steady-state inactivation and intermediate (IC50 1-2 uM) sensitivity to tetrodotoxin. There is no evidence that Nav1.5 channels influence excitability of sensory neurons or play a role in neuropathic pain mechanisms. Because Nav1.5 is the predominant channel expressed in cardiac muscle, therapeutics that exert pronounced effects on Nav1.5 activity can induce adverse side-effects and often have relatively narrow therapeutic windows if used systemically. 


\section{Pharmacology of Voltage-gated sodium channels}

Sodium channels are sensitive to modulation by a variety of pharmacological agents (Catterall 1999; Cestele and Catterall 2000), some of which, such as TTX, can block these channels with a high degree of selectivity. TTX and other toxins have been invaluable to understanding the functional properties of sodium channels and the roles that they play in electrogenesis. Other agents that interact with sodium channels, such as local anesthetics (LA), class I antiarrhythmic drugs and anticonvulsants, have been used to treat pain, epilepsy, ataxias and other pathophysiological conditions (Ragsdale and Avoli 1998;Clare et al. 2000). Local anesthetics are clearly useful in many clinical situations for the treatment of pain, although they can have limited usefulness for treating neuropathic pain. Typically the clinically relevant modulators (such as lidocaine and carbamazepine) result in a complex inhibition of voltage-gated sodium currents, producing both tonic and phasic (use-dependent) block of sodium currents that often involves negative shifts in the voltage-dependence of steady-state inactivation, indicative of enhanced binding to inactivated channels. Although these drugs are very useful clinically, they do not always show high specificity for sodium channels over other types of ion channels, and in general there are only subtle differences in their effects on the different sodium channel isoforms. Recent studies on peripheral neuronal isoforms indicate Nav1.8 may differ in its sensitivity to some of these compounds. Cardenas et al. (2006) reported that the interaction between carbamazepine and Nav1.8-like currents in DRG neurons was slower than the interaction between TTX-sensitive channels and carbamazepine. It is not clear if these differences might be clinically relevant or if compounds that bind to the local anesthetic site can be developed that show enhanced isoform selectivity. Interestingly, it has been proposed that the novel small molecule inhibitor of Nav1.8 (A-803467; Jarvis et al. 2007) may bind at a distinct site from the local anesthetic binding site.

As mentioned above, MrVIb, a muO-conotoxin, selectively blocks Nav1.8 currents and is able to produce substantial analgesia (Bulaj et al., 2006;Ekberg et al., 2006), suggesting that Nav1.8 selective antagonists may have better therapeutic indices for treating pain than the currently available nonselective antagonists that target VGSC. A number of other toxins have been identified that show interesting biological activity against sodium currents and at least five distinct toxin binding sites have been identified on the sodium channel (Cestele and Catterall 2000). While it is beyond the scope of this discussion to list them all, it is interesting to note that peptidic toxins isolated from tarantulas have recently been reported to show inhibitory activity against different voltage-gated sodium currents (Middleton et al. 2002;Peng et al. 2002;Xiao and Liang 2003;Smith et al. 2007) and, along with marine conotoxins, could be an important source of novel sodium channel inhibitors.

\section{Summary}

It has been hypothesized for many years that voltage-gated sodium channels might play specialized roles in nociception and pain mechanisms. It is clear from animal studies that Nav1.7, Nav1.8 and Nav1.9 all play important roles in inflammatory pain. Human studies have shown Nav1.7 is crucial for experiencing physiological pain sensations and small alterations to Nav1.7 can result in severe chronic pain sensations. However, while there is substantial evidence implicating sodium channels in neuropathic pain, it is not clear which sodium channel isoforms contribute to specific types of human neuropathic pain syndromes. Because of its nearly exclusive expression in DRG neurons and its physiological coupling to Nav1.7, Nav1.8 is an attractive candidate. Nav1.3 also merits further study; although some animal studies suggest Nav1.3 does not play a role in peripheral pain mechanisms, other results suggest Nav1.3 may play a role in neuropathic pain. The restricted expression patterns of the VGSCs that are associated with pain makes them very appealing targets for the development of novel analgesics. Unfortunately the sodium channel blockers currently available are not considered 
selective and have relatively narrow therapeutic windows, which can limit their usefulness. Isoform selective pharmacological blockers or gene therapy approaches targeted at downregulating specific isoforms could show increased therapeutic efficacy for treating pain and this is a important area of sodium channel research. Future studies are needed to determine if alterations in the activity of specific sodium channel isoforms underlie common forms of human pain disorders.

\section{Acknowledgements}

TRC was supported by research grant NS053422 from the National Institute of Health. PLS was supported by the Paul and Carole Stark Fellowship. SGW is supported in part by grants from the National Multiple Sclerosis Society and the Rehabilitation Research and Development Service and Medical Research Service, Department of Veterans Affairs. The Center for Neuroscience and Regeneration Research is a Collaboration of the Paralyzed Veterans of America and the United Spinal Association with Yale University.

\section{References}

Akopian AN, Sivilotti L, Wood JN. A tetrodotoxin-resistant voltage-gated sodium channel expressed by sensory neurons. Nature 1996;379:257-262. [PubMed: 8538791]

Akopian AN, Souslova V, England S, Okuse K, Ogata N, Ure J, Smith A, Kerr BJ, McMahon SB, Boyce S, Hill R, Stanfa LC, Dickenson AH, Wood JN. The tetrodotoxin-resistant sodium channel SNS has a specialized function in pain pathways. Nat Neurosci 1999;2:541-548. [PubMed: 10448219]

Akopian AN, Souslova V, Sivilotti L, Wood JN. Structure and distribution of a broadly expressed atypical sodium channel. FEBS Lett 1997;400:183-187. [PubMed: 9001394]

Amaya F, Decosterd I, Samad TA, Plumpton C, Tate S, Mannion RJ, Costigan M, Woolf CJ. Diversity of expression of the sensory neuron-specific TTX-resistant voltage-gated sodium ion channels SNS and SNS2. Mol Cell Neurosci 2000;15:331-342. [PubMed: 10845770]

Amaya F, Wang H, Costigan M, Allchorne AJ, Hatcher JP, Egerton J, Stean T, Morisset V, Grose D, Gunthorpe MJ, Chessell IP, Tate S, Green PJ, Woolf CJ. The voltage-gated sodium channel Na(v)1.9 is an effector of peripheral inflammatory pain hypersensitivity. J Neurosci 2006;26:12852-12860. [PubMed: 17167076]

Arbuckle JB, Docherty RJ. Expression of tetrodotoxin-resistant sodium channels in capsaicin-sensitive dorsal root ganglion neurons of adult rats. Neurosci Lett 1995;185:70-73. [PubMed: 7537359]

Baer M, Best PM, Reuter H. Voltage-dependent action of tetrodotoxin in mammalian cardiac muscle. Nature 1976;263:344-345. [PubMed: 958493]

Baker MD, Bostock H. Low-threshold, persistent sodium current in rat large dorsal root ganglion neurons in culture. J Neurophysiol 1997;77:1503-1513. [PubMed: 9084615]

Baker MD, Chandra SY, Ding Y, Waxman SG, Wood JN. GTP-induced tetrodotoxin-resistant Na+ current regulates excitability in mouse and rat small diameter sensory neurones. J Physiol 2003;548:373-382. [PubMed: 12651922]

Baker MD, Wood JN. Involvement of Na+ channels in pain pathways. Trends Pharmacol Sci 2001;22:2731. [PubMed: 11165669]

Beckh S, Noda M, Lubbert H, Numa S. Differential regulation of three sodium channel messenger RNAs in the rat central nervous system during development. EMBO J 1989;8:3611-3616. [PubMed: 2555170]

Black JA, Cummins TR, Plumpton C, Chen YH, Hormuzdiar W, Clare JJ, Waxman SG. Upregulation of a silent sodium channel after peripheral, but not central, nerve injury in DRG neurons. J Neurophysiol 1999;82:2776-2785. [PubMed: 10561444]

Black JA, Dib-Hajj S, McNabola K, Jeste S, Rizzo MA, Kocsis JD, Waxman SG. Spinal sensory neurons express multiple sodium channel alpha-subunit mRNAs. Brain Res Mol Brain Res 1996;43:117-131. [PubMed: 9037525]

Black JA, Liu S, Tanaka M, Cummins TR, Waxman SG. Changes in the expression of tetrodotoxinsensitive sodium channels within dorsal root ganglia neurons in inflammatory pain. Pain 2004;108:237-247. [PubMed: 15030943] 
Black JA, Renganathan M, Waxman SG. Sodium channel Na(v)1.6 is expressed along nonmyelinated axons and it contributes to conduction. Brain Res Mol Brain Res 2002;105:19-28. [PubMed: 12399104]

Blum R, Kafitz KW, Konnerth A. Neurotrophin-evoked depolarization requires the sodium channel Na (V)1.9. Nature 2002;419:687-693. [PubMed: 12384689]

Boucher TJ, Okuse K, Bennett DL, Munson JB, Wood JN, McMahon SB. Potent analgesic effects of GDNF in neuropathic pain states. Science 2000;290:124-127. [PubMed: 11021795]

Brock JA, McLachlan EM, Belmonte C. Tetrodotoxin-resistant impulses in single nociceptor nerve terminals in guinea-pig cornea. J Physiol 1998;512:211-217. [PubMed: 9729630]

Bulaj G, Zhang MM, Green BR, Fiedler B, Layer RT, Wei S, Nielsen JS, Low SJ, Klein BD, Wagstaff JD, Chicoine L, Harty TP, Terlau H, Yoshikami D, Olivera BM. Synthetic muO-conotoxin MrVIB blocks TTX-resistant sodium channel NaV1.8 and has a long-lasting analgesic activity. Biochemistry 2006;45:7404-7414. [PubMed: 16752929]

Caffrey JM, Eng DL, Black JA, Waxman SG, Kocsis JD. Three types of sodium channels in adult rat dorsal root ganglion neurons. Brain Res 1992;592:283-297. [PubMed: 1280518]

Caldwell JH, Schaller KL, Lasher RS, Peles E, Levinson SR. Sodium channel Na(v)1.6 is localized at nodes of ranvier, dendrites, and synapses. Proc Natl Acad Sci U S A 2000;97:5616-5620. [PubMed: 10779552]

Cardenas CA, Cardenas CG, de Armendi AJ, Scroggs RS. Carbamazepine interacts with a slow inactivation state of NaV1.8-like sodium channels. Neurosci Lett 2006;408:129-134. [PubMed: 16978779]

Catterall WA. Molecular properties of brain sodium channels: an important target for anticonvulsant drugs. Adv Neurol 1999;79:441-456. [PubMed: 10514834]

Catterall WA. From ionic currents to molecular mechanisms: the structure and function of voltage-gated sodium channels. Neuron 2000;26:13-25. [PubMed: 10798388]

Cestele S, Catterall WA. Molecular mechanisms of neurotoxin action on voltage-gated sodium channels. Biochimie 2000;82:883-892. [PubMed: 11086218]

Chen C, Westenbroek RE, Xu X, Edwards CA, Sorenson DR, Chen Y, McEwen DP, O’Malley HA, Bharucha V, Meadows LS, Knudsen GA, Vilaythong A, Noebels JL, Saunders TL, Scheuer T, Shrager P, Catterall WA, Isom LL. Mice lacking sodium channel beta1 subunits display defects in neuronal excitability, sodium channel expression, and nodal architecture. J Neurosci 2004;24:40304042. [PubMed: 15102918]

Chen YH, Dale TJ, Romanos MA, Whitaker WR, Xie XM, Clare JJ. Cloning, distribution and functional analysis of the type III sodium channel from human brain. Eur J Neurosci 2000;12:4281-4289. [PubMed: 11122339]

Choi JS, Dib-Hajj SD, Waxman SG. Inherited erythermalgia: limb pain from an S4 charge-neutral Na channelopathy. Neurology 2006;67:1563-1567. [PubMed: 16988069]

Clare JJ, Tate SN, Nobbs M, Romanos MA. Voltage-gated sodium channels as therapeutic targets. Drug Discov Today 2000;5:506-520. [PubMed: 11084387]

Coste B, Osorio N, Padilla F, Crest M, Delmas P. Gating and modulation of presumptive NaV1.9 channels in enteric and spinal sensory neurons. Mol Cell Neurosci 2004;26:123-34. [PubMed: 15121184]

Cox JJ, Reimann F, Nicholas AK, Thornton G, Roberts E, Springell K, Karbani G, Jafri H, Mannan J, Raashid Y, Al-Gazali L, Hamamy H, Valente EM, Gorman S, Williams R, McHale DP, Wood JN, Gribble FM, Woods CG. An SCN9A channelopathy causes congenital inability to experience pain. Nature 2006;444:894-898. [PubMed: 17167479]

Crill WE. Persistent sodium current in mammalian central neurons. Annu Rev Physiol 1996;58:349-362. [PubMed: 8815799]

Cummins TR, Aglieco F, Renganathan M, Herzog RI, Dib-Hajj SD, Waxman SG. Nav1.3 sodium channels: rapid repriming and slow closed-state inactivation display quantitative differences after expression in a mammalian cell line and in spinal sensory neurons. J Neurosci 2001;21:5952-5961. [PubMed: 11487618]

Cummins TR, Black JA, Dib-Hajj SD, Waxman SG. Glial-derived neurotrophic factor upregulates expression of functional SNS and NaN sodium channels and their currents in axotomized dorsal root ganglion neurons. J Neurosci 2000;20:8754-8761. [PubMed: 11102483] 
Cummins TR, Dib-Hajj SD, Black JA, Akopian AN, Wood JN, Waxman SG. A novel persistent tetrodotoxin-resistant sodium current in SNS-null and wild-type small primary sensory neurons. J Neurosci 1999;19:RC43. [PubMed: 10594087]

Cummins TR, Dib-Hajj SD, Herzog RI, Waxman SG. Nav1.6 channels generate resurgent sodium currents in spinal sensory neurons. FEBS Lett 2005;579:2166-2170. [PubMed: 15811336]

Cummins TR, Dib-Hajj SD, Waxman SG. Electrophysiological properties of mutant Nav1.7 sodium channels in a painful inherited neuropathy. J Neurosci 2004;24:8232-8236. [PubMed: 15385606]

Cummins TR, Howe JR, Waxman SG. Slow closed-state inactivation: a novel mechanism underlying ramp currents in cells expressing the hNE/PN1 sodium channel. J Neurosci 1998;18:9607-9619. [PubMed: 9822722]

Cummins TR, Waxman SG. Downregulation of tetrodotoxin-resistant sodium currents and upregulation of a rapidly repriming tetrodotoxin-sensitive sodium current in small spinal sensory neurons after nerve injury. J Neurosci 1997;17:3503-3514. [PubMed: 9133375]

Decosterd I, Ji RR, Abdi S, Tate S, Woolf CJ. The pattern of expression of the voltage-gated sodium channels $\mathrm{Na}(\mathrm{v}) 1.8$ and $\mathrm{Na}(\mathrm{v}) 1.9$ does not change in uninjured primary sensory neurons in experimental neuropathic pain models. Pain 2002;96:269-277. [PubMed: 11972999]

Dib-Hajj S, Black JA, Cummins TR, Waxman SG. NaN/Nav1.9: a sodium channel with unique properties. Trends Neurosci 2002;25:253-259. [PubMed: 11972962]

Dib-Hajj S, Black JA, Felts P, Waxman SG. Down-regulation of transcripts for Na channel alpha-SNS in spinal sensory neurons following axotomy. Proc Natl Acad Sci U S A 1996;93:14950-14954. [PubMed: 8962162]

Dib-Hajj SD, Rush AM, Cummins TR, Hisama FM, Novella S, Tyrrell L, Marshall L, Waxman SG. Gain-of-function mutation in Nav1.7 in familial erythromelalgia induces bursting of sensory neurons. Brain 2005;128:1847-1854. [PubMed: 15958509]

Dib-Hajj SD, Tyrrell L, Black JA, Waxman SG. NaN, a novel voltage-gated Na channel, is expressed preferentially in peripheral sensory neurons and down-regulated after axotomy. Proc Natl Acad Sci U S A 1998;95:8963-8968. [PubMed: 9671787]

Dib-Hajj SD, Tyrrell L, Cummins TR, Black JA, Wood PM, Waxman SG. Two tetrodotoxin-resistant sodium channels in human dorsal root ganglion neurons. FEBS Lett 1999;462:117-120. [PubMed: 10580103]

Dichgans M, Freilinger T, Eckstein G, Babini E, Lorenz-Depiereux B, Biskup S, Ferrari MD, Herzog J, van den Maagdenberg AM, Pusch M, Strom TM. Mutation in the neuronal voltage-gated sodium channel SCN1A in familial hemiplegic migraine. Lancet 2005;366:371-377. [PubMed: 16054936]

Djouhri L, Newton R, Levinson SR, Berry CM, Carruthers B, Lawson SN. Sensory and electrophysiological properties of guinea-pig sensory neurones expressing Nav 1.7 (PN1) Na+ channel alpha subunit protein. J Physiol 2003;546:565-576. [PubMed: 12527742]

Dong XW, Goregoaker S, Engler H, Zhou X, Mark L, Crona J, Terry R, Hunter J, Priestley T. Small interfering RNA-mediated selective knockdown of $\mathrm{Na}(\mathrm{V}) 1.8$ tetrodotoxin-resistant sodium channel reverses mechanical allodynia in neuropathic rats. Neuroscience 2007;146:812-21. [PubMed: 17367951]

Drenth JP, te Morsche RH, Guillet G, Taieb A, Kirby RL, Jansen JB. SCN9A mutations define primary erythermalgia as a neuropathic disorder of voltage gated sodium channels. J Invest Dermatol 2005;124:1333-1338. [PubMed: 15955112]

Ekberg J, Jayamanne A, Vaughan CW, Aslan S, Thomas L, Mould J, Drinkwater R, Baker MD, Abrahamsen B, Wood JN, Adams DJ, Christie MJ, Lewis RJ. muO-conotoxin MrVIB selectively blocks Nav1.8 sensory neuron specific sodium channels and chronic pain behavior without motor deficits. Proc Natl Acad Sci U S A 2006;103:17030-17035. [PubMed: 17077153]

Elliott AA, Elliott JR. Characterization of TTX-sensitive and TTX-resistant sodium currents in small cells from adult rat dorsal root ganglia. J Physiol 1993;463:39-56. [PubMed: 8246189]

Everill B, Cummins TR, Waxman SG, Kocsis JD. Sodium currents of large (Abeta-type) adult cutaneous afferent dorsal root ganglion neurons display rapid recovery from inactivation before and after axotomy. Neuroscience 2001;106:161-169. [PubMed: 11564426] 
Fang X, Djouhri L, Black JA, Dib-Hajj SD, Waxman SG, Lawson SN. The presence and role of the tetrodotoxin-resistant sodium channel $\mathrm{Na}(\mathrm{v}) 1.9(\mathrm{NaN})$ in nociceptive primary afferent neurons. $\mathrm{J}$ Neurosci 2002;22:7425-7433. [PubMed: 12196564]

Fang X, Djouhri L, McMullan S, Berry C, Waxman SG, Okuse K, Lawson SN. Intense isolectin-B4 binding in rat dorsal root ganglion neurons distinguishes $\mathrm{C}$-fiber nociceptors with broad action potentials and high Nav1.9 expression. J Neurosci 2006;26:7281-7292. [PubMed: 16822986]

Felts PA, Yokoyama S, Dib-Hajj S, Black JA, Waxman SG. Sodium channel alpha-subunit mRNAs I, II, III, NaG, Na6 and hNE (PN1): different expression patterns in developing rat nervous system. Brain Res Mol Brain Res 1997;45:71-82. [PubMed: 9105672]

Fertleman CR, Baker MD, Parker KA, Moffatt S, Elmslie FV, Abrahamsen B, Ostman J, Klugbauer N, Wood JN, Gardiner RM, Rees M. SCN9A mutations in paroxysmal extreme pain disorder: allelic variants underlie distinct channel defects and phenotypes. Neuron 2006;52:767-774. [PubMed: 17145499]

Fitzgerald EM, Okuse K, Wood JN, Dolphin AC, Moss SJ. cAMP-dependent phosphorylation of the tetrodotoxin-resistant voltage-dependent sodium channel SNS. J Physiol 1999;516(Pt 2):433-446. [PubMed: 10087343]

Garcia KD, Sprunger LK, Meisler MH, Beam KG. The sodium channel Scn8a is the major contributor to the postnatal developmental increase of sodium current density in spinal motoneurons. J Neurosci 1998;18:5234-5239. [PubMed: 9651206]

George AL Jr. Inherited disorders of voltage-gated sodium channels. J Clin Invest 2005;115:1990-1999. [PubMed: 16075039]

Gold MS, Reichling DB, Shuster MJ, Levine JD. Hyperalgesic agents increase a tetrodotoxin-resistant $\mathrm{Na}+$ current in nociceptors. Proc Natl Acad Sci U S A 1996;93:1108-1112. [PubMed: 8577723]

Goldberg Y, Macfarlane J, Macdonald M, Thompson J, Dube MP, Mattice M, Fraser R, Young C, Hossain S, Pape T, Payne B, Radomski C, Donaldson G, Ives E, Cox J, Younghusband H, Green R, Duff A, Boltshauser E, Grinspan G, Dimon J, Sibley B, Andria G, Toscano E, Kerdraon J, Bowsher D, Pimstone S, Samuels M, Sherrington R, Hayden M. Loss-of-function mutations in the Na(v)1.7 gene underlie congenital indifference to pain in multiple human populations. Clin Genet 2007;71:311319. [PubMed: 17470132]

Goldin AL, Barchi RL, Caldwell JH, Hofmann F, Howe JR, Hunter JC, Kallen RG, Mandel G, Meisler MH, Netter YB, Noda M, Tamkun MM, Waxman SG, Wood JN, Catterall WA. Nomenclature of voltage-gated sodium channels. Neuron 2000;28:365-368. [PubMed: 11144347]

Grieco TM, Afshari FS, Raman IM. A role for phosphorylation in the maintenance of resurgent sodium current in cerebellar purkinje neurons. J Neurosci 2002;22:3100-3107. [PubMed: 11943813]

Grieco TM, Malhotra JD, Chen C, Isom LL, Raman IM. Open-channel block by the cytoplasmic tail of sodium channel beta4 as a mechanism for resurgent sodium current. Neuron 2005;45:233-244. [PubMed: 15664175]

Hains BC, Klein JP, Saab CY, Craner MJ, Black JA, Waxman SG. Upregulation of sodium channel Nav1.3 and functional involvement in neuronal hyperexcitability associated with central neuropathic pain after spinal cord injury. J Neurosci 2003;23:8881-8892. [PubMed: 14523090]

Hains BC, Saab CY, Klein JP, Craner MJ, Waxman SG. Altered sodium channel expression in secondorder spinal sensory neurons contributes to pain after peripheral nerve injury. J Neurosci 2004;24:4832-4839. [PubMed: 15152043]

Hamill OP, Marty A, Neher E, Sakmann B, Sigworth FJ. Improved patch-clamp techniques for highresolution current recording from cells and cell-free membrane patches. Pflugers Arch 1981;391:85100. [PubMed: 6270629]

Han C, Rush AM, Dib-Hajj SD, Li S, Xu Z, Wang Y, Tyrrell L, Wang X, Yang Y, Waxman SG. Sporadic onset of erythermalgia: A gain-of-function mutation in Na(v)1.7. Ann Neurol 2006;59:553-558. [PubMed: 16392115]

Harper AA, Lawson SN. Conduction velocity is related to morphological cell type in rat dorsal root ganglion neurones. J Physiol 1985;359:31-46. [PubMed: 3999040]

Harty TP, Dib-Hajj SD, Tyrrell L, Blackman R, Hisama FM, Rose JB, Waxman SG. Na(V)1.7 mutant A863P in erythromelalgia: effects of altered activation and steady-state inactivation on excitability of nociceptive dorsal root ganglion neurons. J Neurosci 2006;26:12566-12575. [PubMed: 17135418] 
Herzog RI, Cummins TR, Ghassemi F, Dib-Hajj SD, Waxman SG. Distinct repriming and closed-state inactivation kinetics of Nav1.6 and Nav1.7 sodium channels in mouse spinal sensory neurons. J Physiol 2003a;551:741-750. [PubMed: 12843211]

Herzog RI, Cummins TR, Waxman SG. Persistent TTX-resistant Na+ current affects resting potential and response to depolarization in simulated spinal sensory neurons. J Neurophysiol 2001;86:13511364. [PubMed: 11535682]

Herzog RI, Liu C, Waxman SG, Cummins TR. Calmodulin binds to the $\mathrm{C}$ terminus of sodium channels Nav1.4 and Nav1.6 and differentially modulates their functional properties. J Neurosci 2003b; 23:8261-8270. [PubMed: 12967988]

Hiyama TY, Watanabe E, Ono K, Inenaga K, Tamkun MM, Yoshida S, Noda M. Na(x) channel involved in CNS sodium-level sensing. Nat Neurosci 2002;5:511-512. [PubMed: 11992118]

Hong S, Morrow TJ, Paulson PE, Isom LL, Wiley JW. Early painful diabetic neuropathy is associated with differential changes in tetrodotoxin-sensitive and -resistant sodium channels in dorsal root ganglion neurons in the rat. J Biol Chem 2004;279:29341-29350. [PubMed: 15123645]

Isom LL. Sodium channel beta subunits: anything but auxiliary. Neuroscientist 2001;7:42-54. [PubMed: 11486343]

Jarvis MF, Honore P, Shieh CC, Chapman M, Joshi S, Zhang XF, Kort M, Carroll W, Marron B, Atkinson R, Thomas J, Liu D, Krambis M, Liu Y, McGaraughty S, Chu K, Roeloffs R, Zhong C, Mikusa JP, Hernandez G, Gauvin D, Wade C, Zhu C, Pai M, Scanio M, Shi L, Drizin I, Gregg R, Matulenko M, Hakeem A, Gross M, Johnson M, Marsh K, Wagoner PK, Sullivan JP, Faltynek CR, Krafte DS. A-803467, a potent and selective Nav1.8 sodium channel blocker, attenuates neuropathic and inflammatory pain in the rat. Proc Natl Acad Sci U S A. 2007

Joshi SK, Mikusa JP, Hernandez G, Baker S, Shieh CC, Neelands T, Zhang XF, Niforatos W, Kage K, Han P, Krafte D, Faltynek C, Sullivan JP, Jarvis MF, Honore P. Involvement of the TTX-resistant sodium channel Nav 1.8 in inflammatory and neuropathic, but not post-operative, pain states. Pain 2006;123:75-82. [PubMed: 16545521]

Kerr BJ, Souslova V, McMahon SB, Wood JN. A role for the TTX-resistant sodium channel Nav 1.8 in NGF-induced hyperalgesia, but not neuropathic pain 1. Neuroreport 2001;12:3077-3080. [PubMed: 11568640]

Khaliq ZM, Gouwens NW, Raman IM. The contribution of resurgent sodium current to high-frequency firing in Purkinje neurons: an experimental and modeling study. J Neurosci 2003;23:4899-4912. [PubMed: 12832512]

Khasar SG, Gold MS, Levine JD. A tetrodotoxin-resistant sodium current mediates inflammatory pain in the rat. Neurosci Lett 1998;256:17-20. [PubMed: 9832206]

Kim CH, Oh Y, Chung JM, Chung K. Changes in three subtypes of tetrodotoxin sensitive sodium channel expression in the axotomized dorsal root ganglion in the rat. Neurosci Lett 2002;323:125-128. [PubMed: 11950509]

Klugbauer N, Lacinova L, Flockerzi V, Hofmann F. Structure and functional expression of a new member of the tetrodotoxin-sensitive voltage-activated sodium channel family from human neuroendocrine cells. EMBO J 1995;14:1084-1090. [PubMed: 7720699]

Kostyuk PG, Veselovsky NS, Tsyndrenko AY. Ionic currents in the somatic membrane of rat dorsal root ganglion neurons-I. Sodium currents. Neuroscience 1981;6:2423-2430. [PubMed: 6275294]

Lai J, Gold MS, Kim CS, Bian D, Ossipov MH, Hunter JC, Porreca F. Inhibition of neuropathic pain by decreased expression of the tetrodotoxin-resistant sodium channel, NaV1.8. Pain 2002;95:143-152. [PubMed: 11790477]

Lampert A, Hains BC, Waxman SG. Upregulation of persistent and ramp sodium current in dorsal horn neurons after spinal cord injury. Exp Brain Res 2006;174:660-666. [PubMed: 16718433]

Lee KH, Chung K, Chung JM, Coggeshall RE. Correlation of cell body size, axon size, and signal conduction velocity for individually labelled dorsal root ganglion cells in the cat. J Comp Neurol 1986;243:335-346. [PubMed: 3950079]

Lee MJ, Yu HS, Hsieh ST, Stephenson DA, Lu CJ, Yang CC. Characterization of a familial case with primary erythromelalgia from Taiwan. J Neurol 2007;254:210-214. [PubMed: 17294067] 
Leffler A, Herzog RI, Dib-Hajj SD, Waxman SG, Cummins TR. Pharmacological properties of neuronal TTX-resistant sodium channels and the role of a critical serine pore residue. Pflugers Arch 2005;451:454-463. [PubMed: 15981012]

Lindia JA, Kohler MG, Martin WJ, Abbadie C. Relationship between sodium channel NaV1.3 expression and neuropathic pain behavior in rats. Pain 2005;117:145-153. [PubMed: 16061326]

Lossin C, Wang DW, Rhodes TH, Vanoye CG, George AL Jr. Molecular basis of an inherited epilepsy. Neuron 2002;34:877-884. [PubMed: 12086636]

Matzner O, Devor M. Hyperexcitability at sites of nerve injury depends on voltage-sensitive Na+ channels. J Neurophysiol 1994;72:349-359. [PubMed: 7965019]

Meadows LS, Chen YH, Powell AJ, Clare JJ, Ragsdale DS. Functional modulation of human brain Nav1.3 sodium channels, expressed in mammalian cells, by auxiliary beta 1, beta 2 and beta 3 subunits. Neuroscience 2002;114:745-753. [PubMed: 12220575]

Michiels JJ, te Morsche RH, Jansen JB, Drenth JP. Autosomal dominant erythermalgia associated with a novel mutation in the voltage-gated sodium channel alpha subunit Nav1.7. Arch Neurol 2005;62:1587-1590. [PubMed: 16216943]

Middleton RE, Warren VA, Kraus RL, Hwang JC, Liu CJ, Dai G, Brochu RM, Kohler MG, Gao YD, Garsky VM, Bogusky MJ, Mehl JT, Cohen CJ, Smith MM. Two tarantula peptides inhibit activation of multiple sodium channels. Biochemistry 2002;41:14734-14747. [PubMed: 12475222]

Nassar MA, Baker MD, Levato A, Ingram R, Mallucci G, McMahon SB, Wood JN. Nerve injury induces robust allodynia and ectopic discharges in Nav1.3 null mutant mice. Mol Pain 2006;2:33. [PubMed: 17052333]

Nassar MA, Levato A, Stirling LC, Wood JN. Neuropathic pain develops normally in mice lacking both Nav1.7 and Nav1.8. Mol Pain 2005;1:24. [PubMed: 16111501]

Nassar MA, Stirling LC, Forlani G, Baker MD, Matthews EA, Dickenson AH, Wood JN. Nociceptorspecific gene deletion reveals a major role for Nav1.7 (PN1) in acute and inflammatory pain. Proc Natl Acad Sci U S A 2004;101:12706-12711. [PubMed: 15314237]

Ogata K, Jeong SY, Murakami H, Hashida H, Suzuki T, Masuda N, Hirai M, Isahara K, Uchiyama Y, Goto J, Kanazawa I. Cloning and expression study of the mouse tetrodotoxin-resistant voltage-gated sodium channel alpha subunit NaT/Scn11a. Biochem Biophys Res Commun 2000;267:271-7. [PubMed: 10623609]

Okuse K, Malik-Hall M, Baker MD, Poon WY, Kong H, Chao MV, Wood JN. Annexin II light chain regulates sensory neuron-specific sodium channel expression. Nature 2002;417:653-656. [PubMed: 12050667]

Pan F, Beam KG. The absence of resurgent sodium current in mouse spinal neurons. Brain Res 1999;849:162-168. [PubMed: 10592298]

Peng K, Shu Q, Liu Z, Liang S. Function and solution structure of huwentoxin-IV, a potent neuronal tetrodotoxin (TTX)-sensitive sodium channel antagonist from Chinese bird spider Selenocosmia huwena. J Biol Chem 2002;277:47564-47571. [PubMed: 12228241]

Priest BT, Murphy BA, Lindia JA, Diaz C, Abbadie C, Ritter AM, Liberator P, Iyer LM, Kash SF, Kohler MG, Kaczorowski GJ, MacIntyre DE, Martin WJ. Contribution of the tetrodotoxin-resistant voltage-gated sodium channel NaV1.9 to sensory transmission and nociceptive behavior. Proc Natl Acad Sci U S A 2005;102:9382-9387. [PubMed: 15964986]

Ragsdale DS, Avoli M. Sodium channels as molecular targets for antiepileptic drugs. Brain Res Brain Res Rev 1998;26:16-28. [PubMed: 9600622]

Raman IM, Bean BP. Resurgent sodium current and action potential formation in dissociated cerebellar Purkinje neurons. J Neurosci 1997;17:4517-4526. [PubMed: 9169512]

Raman IM, Sprunger LK, Meisler MH, Bean BP. Altered subthreshold sodium currents and disrupted firing patterns in Purkinje neurons of Scn8a mutant mice. Neuron 1997;19:881-891. [PubMed: 9354334]

Renganathan M, Cummins TR, Waxman SG. Contribution of $\mathrm{Na}(\mathrm{v}) 1.8$ sodium channels to action potential electrogenesis in DRG neurons. J Neurophysiol 2001;86:629-640. [PubMed: 11495938]

Renganathan M, Dib-Hajj S, Waxman SG. Na(v)1.5 underlies the 'third TTX-R sodium current' in rat small DRG neurons. Brain Res Mol Brain Res 2002;106:70-82. [PubMed: 12393266] 
Ritchie JM, Rogart RB. The binding of saxitoxin and tetrodotoxin to excitable tissue. Rev Physiol Biochem Pharmacol 1977;79:1-50. [PubMed: 335473]

Rogart RB, Cribbs LL, Muglia LK, Kephart DD, Kaiser MW. Molecular cloning of a putative tetrodotoxin-resistant rat heart Na+ channel isoform. Proc Natl Acad Sci U S A 1989;86:8170 8174. [PubMed: 2554302]

Roy ML, Narahashi T. Differential properties of tetrodotoxin-sensitive and tetrodotoxin-resistant sodium channels in rat dorsal root ganglion neurons. J Neurosci 1992;12:2104-2111. [PubMed: 1318956]

Rugiero F, Mistry M, Sage D, Black JA, Waxman SG, Crest M, Clerc N, Delmas P, Gola M. Selective expression of a persistent tetrodotoxin-resistant $\mathrm{Na}+$ current and $\mathrm{NaV} 1.9$ subunit in myenteric sensory neurons. J Neurosci 2003;23:2715-2725. [PubMed: 12684457]

Rush AM, Craner MJ, Kageyama T, Dib-Hajj SD, Waxman SG, Ranscht B. Contactin regulates the current density and axonal expression of tetrodotoxin-resistant but not tetrodotoxin-sensitive sodium channels in DRG neurons. Eur J Neurosci 2005;22:39-49. [PubMed: 16029194]

Rush AM, Dib-Hajj SD, Liu S, Cummins TR, Black JA, Waxman SG. A single sodium channel mutation produces hyper- or hypoexcitability in different types of neurons. Proc Natl Acad Sci U S A 2006a; 103:8245-8250. [PubMed: 16702558]

Rush AM, Waxman SG. PGE2 increases the tetrodotoxin-resistant Nav1.9 sodium current in mouse DRG neurons via G-proteins. Brain Res 2004;1023:264-271. [PubMed: 15374752]

Rush AM, Wittmack EK, Tyrrell L, Black JA, Dib-Hajj SD, Waxman SG. Differential modulation of sodium channel $\mathrm{Na}(\mathrm{v}) 1.6$ by two members of the fibroblast growth factor homologous factor 2 subfamily. Eur J Neurosci 2006b;23:2551-2562. [PubMed: 16817858]

Sangameswaran L, Delgado SG, Fish LM, Koch BD, Jakeman LB, Stewart GR, Sze P, Hunter JC, Eglen RM, Herman RC. Structure and function of a novel voltage-gated, tetrodotoxin-resistant sodium channel specific to sensory neurons. J Biol Chem 1996;271:5953-5956. [PubMed: 8626372]

Sangameswaran L, Fish LM, Koch BD, Rabert DK, Delgado SG, Ilnicka M, Jakeman LB, Novakovic S, Wong K, Sze P, Tzoumaka E, Stewart GR, Herman RC, Chan H, Eglen RM, Hunter JC. A novel tetrodotoxin-sensitive, voltage-gated sodium channel expressed in rat and human dorsal root ganglia 7. J Biol Chem 1997;272:14805-14809. [PubMed: 9169448]

Shah BS, Stevens EB, Gonzalez MI, Bramwell S, Pinnock RD, Lee K, Dixon AK. beta3, a novel auxiliary subunit for the voltage-gated sodium channel, is expressed preferentially in sensory neurons and is upregulated in the chronic constriction injury model of neuropathic pain. Eur J Neurosci 2000;12:3985-3990. [PubMed: 11069594]

Sheets PL, Jackson Ii JO, Waxman SG, Dib-Hajj S, Cummins TR. A Nav1.7 Channel Mutation Associated with Hereditary Erythromelalgia Contributes to Neuronal Hyperexcitability and Displays Reduced Lidocaine Sensitivity. J Physiol. 2007

Smith JJ, Cummins TR, Alphy S, Blumenthal KM. Molecular Interactions of the Gating Modifier Toxin ProTx-II with Nav1.5: Implied Existence of a Novel Toxin Binding Site Coupled to Activation. J Biol Chem 2007;282:12687-12697. [PubMed: 17339321]

Smith RD, Goldin AL. Functional analysis of the rat I sodium channel in xenopus oocytes. J Neurosci 1998;18:811-820. [PubMed: 9437003]

Tanaka M, Cummins TR, Ishikawa K, Dib-Hajj SD, Black JA, Waxman SG. SNS Na+ channel expression increases in dorsal root ganglion neurons in the carrageenan inflammatory pain model. Neuroreport 1998;9:967-972. [PubMed: 9601651]

Tate S, Benn S, Hick C, Trezise D, John V, Mannion RJ, Costigan M, Plumpton C, Grose D, Gladwell Z, Kendall G, Dale K, Bountra C, Woolf CJ. Two sodium channels contribute to the TTX-R sodium current in primary sensory neurons. Nat Neurosci 1998;1:653-655. [PubMed: 10196578]

Toledo-Aral JJ, Moss BL, He ZJ, Koszowski AG, Whisenand T, Levinson SR, Wolf JJ, Silos-Santiago I, Halegoua S, Mandel G. Identification of PN1, a predominant voltage-dependent sodium channel expressed principally in peripheral neurons. Proc Natl Acad Sci U S A 1997;94:1527-1532. [PubMed: 9037087]

Trimmer JS, Cooperman SS, Tomiko SA, Zhou JY, Crean SM, Boyle MB, Kallen RG, Sheng ZH, Barchi RL, Sigworth FJ. Primary structure and functional expression of a mammalian skeletal muscle sodium channel. Neuron 1989;3:33-49. [PubMed: 2559760] 
Trimmer JS, Rhodes KJ. Localization of voltage-gated ion channels in mammalian brain. Annu Rev Physiol 2004;66:477-519. [PubMed: 14977411]

Waxman SG, Kocsis JD, Black JA. Type III sodium channel mRNA is expressed in embryonic but not adult spinal sensory neurons, and is reexpressed following axotomy. J Neurophysiol 1994;72:466470. [PubMed: 7965028]

West JW, Patton DE, Scheuer T, Wang Y, Goldin AL, Catterall WA. A cluster of hydrophobic amino acid residues required for fast $\mathrm{Na}(+)$-channel inactivation. Proc Natl Acad Sci U S A 1992;89:10910-10914. [PubMed: 1332060]

Xiao Y, Liang S. Inhibition of neuronal tetrodotoxin-sensitive Na+ channels by two spider toxins: hainantoxin-III and hainantoxin-IV. Eur J Pharmacol 2003;477:1-7. [PubMed: 14512091]

Yang Y, Wang Y, Li S, Xu Z, Li H, Ma L, Fan J, Bu D, Liu B, Fan Z, Wu G, Jin J, Ding B, Zhu X, Shen Y. Mutations in SCN9A, encoding a sodium channel alpha subunit, in patients with primary erythermalgia. J Med Genet 2004;41:171-174. [PubMed: 14985375]

Yeomans DC, Levinson SR, Peters MC, Koszowski AG, Tzabazis AZ, Gilly WF, Wilson SP. Decrease in inflammatory hyperalgesia by herpes vector-mediated knockdown of Nav1.7 sodium channels in primary afferents. Hum Gene Ther 2005;16:271-277. [PubMed: 15761266]

Yu FH, Westenbroek RE, Silos-Santiago I, McCormick KA, Lawson D, Ge P, Ferriera H, Lilly J, DiStefano PS, Catterall WA, Scheuer T, Curtis R. Sodium channel beta4, a new disulfide-linked auxiliary subunit with similarity to beta2. J Neurosci 2003;23:7577-7585. [PubMed: 12930796]

Zhang YH, Fehrenbacher JC, Vasko MR, Nicol GD. Sphingosine-1-phosphate via activation of a Gprotein-coupled receptor(s) enhances the excitability of rat sensory neurons. J Neurophysiol 2006;96:1042-1052. [PubMed: 16723416]

Zhang YH, Vasko MR, Nicol GD. Ceramide, a putative second messenger for nerve growth factor, modulates the TTX-resistant $\mathrm{Na}(+)$ current and delayed rectifier $\mathrm{K}(+)$ current in rat sensory neurons. J Physiol 2002;544:385-402. [PubMed: 12381813] 
A
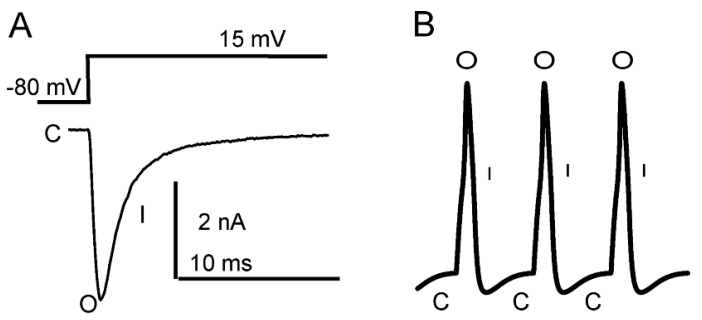

C

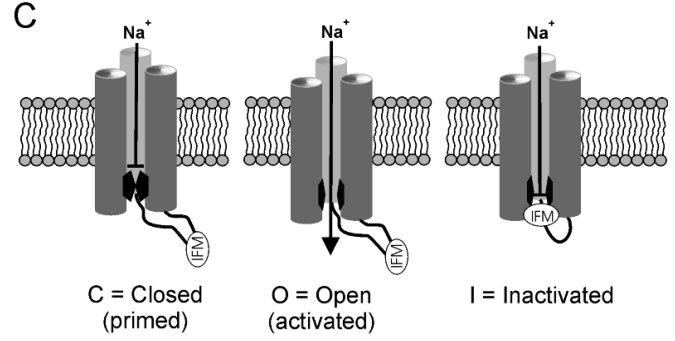

Figure 1.

A, Voltage clamp recording from Nav1.7 channels showing typical voltage-gated sodium currents. The downward deflection reflects the inward movement of sodium ions in response to a depolarizing voltage pulse from a holding potential of $-80 \mathrm{mV}$. The channel is closed (C) at $-80 \mathrm{mV}$ and when pulsed to $+15 \mathrm{mV}$ the channel opens $(\mathrm{O})$ and rapidly inactivates (I). B, A simple action potential schematic indicating where in the action potential waveform you would expect voltage-gated sodium channels to be closed, open, or inactivated. C, Diagram indicating the proposed scheme for voltage-gated sodium channels transitions from closed to open to fastinactivated. 


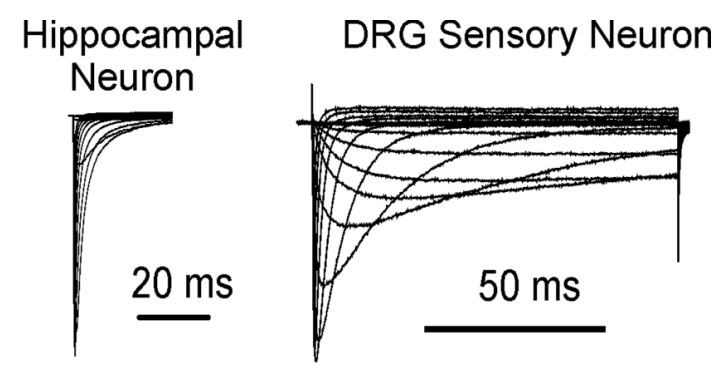

Figure 2.

Comparison of sodium currents recorded from a hippocampal pyramidal CA1 neuron (A) and a small diameter DRG sensory neuron (B). Sodium currents were elicited with step depolarizations from a holding potential of $-100 \mathrm{mV}$ to membrane voltages ranging from -80 to $40 \mathrm{mV}$. The inactivation phase of the DRG sodium currents is more complex than that of the hippocampal neuron, suggesting the presence of multiple sodium channel subtypes. 


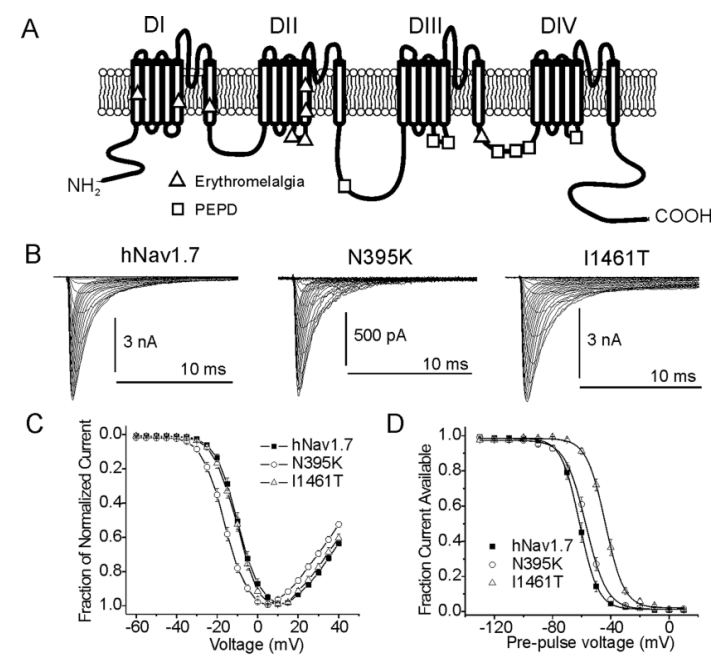

\section{Figure 3.}

A, Linear diagram of a Nav1.7 voltage-gated sodium channel showing locations of single pointmutations indicated in the painful neuropathies erythromelalgia and Paroxymsal Extreme Pain Disorder (PEPD). B, $\mathrm{Na}^{+}$current traces from the wild-type human Nav1.7 channel and from $\mathrm{Na}_{\mathrm{v}} 1.7$ channels containing an erythromelalgia mutation (N395K) and a PEPD mutation (I1461T). C, Current-voltage (IV) profile for wild-type, N395K, and I1461T Nav1.7 channels. All erythromelalgia mutations cause a hyperpolarizing shift in the voltage-dependence of activation for Nav1.7 channels while PEPD mutations thus far show no effects on activation. D, Steady-state fast inactivation profile for wild-type, N395K, and I1461T Nav1.7 channels. PEPD mutations cause a depolarizing shift in the voltage-dependence of steady-state fast inactivation while erythromelalgia mutants have little or no effect on fast inactivation properties. 

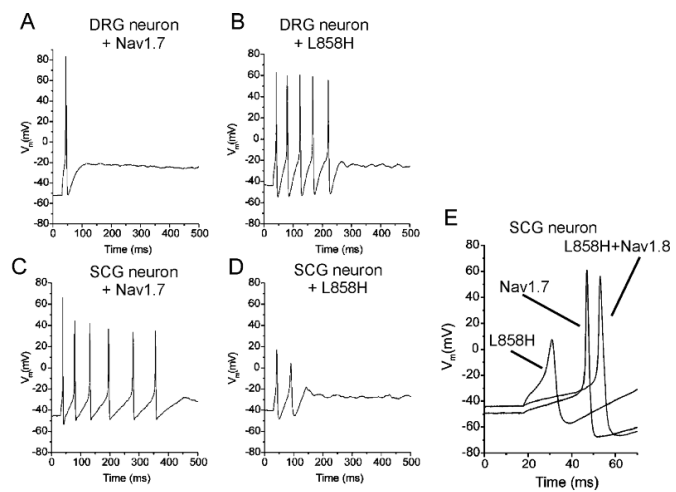

Figure 4.

While the L858H mutation increases firing frequency in DRG neurons and decreases firing frequency in SCG neurons, coexpression of Nav1.8 channels rescues electrogenic properties in SCG neurons. A, Representative DRG neuron expressing wild-type Nav1.7 fires a single action potential in response to a $100 \mathrm{pA}$ stimulus. B, Representative DRG neuron expressing $\mathrm{L} 858 \mathrm{H}$ fires five action potentials in response to a $100 \mathrm{pA}$ stimulus. C, Representative SCG neuron expressing WT Nav1.7 fires six action potentials in response to a 40 pA stimulus. D, Representative SCG neuron expressing L858H fires only two action potentials in response to a 100 pA stimulus. E, Action potentials recorded from representative SCG neurons transfected with wild-type Nav1.7, L858H, and L858H plus Nav1.8 channels. When Nav1.8 was coexpressed with $\mathrm{L} 858 \mathrm{H}$, current threshold and action potential overshoot were restored. Adapted from Rush et al., 2006a. (C) 2006 National Academy of Sciences, USA. 


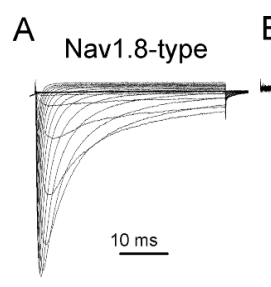

\section{B Nav1.9-type}

C

CFA

Hotplate $50^{\circ} \mathrm{C}$

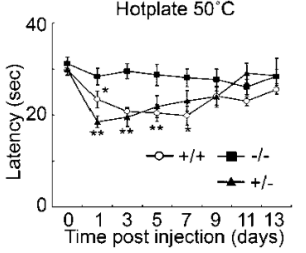

$\mathrm{D}$

Spared Nerve Injury

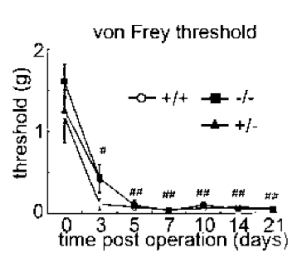

\section{Figure 5.}

Comparison of Nav1.8-type TTX-R sodium currents (A) and Nav1.9-type TTX-R sodium currents (B) recorded from mouse DRG sensory neurons. C, Peripheral inflammation, induced by intraplantar injection of CFA, produced a significant reduction in hotplate latency for $7 \mathrm{~d}$ in wild-type and $\mathrm{Na}_{\mathrm{v}} 1.9^{+/-}$mice, but not for $\mathrm{Na}_{\mathrm{v}} 1.9^{-/-}$mice, indicating that Nav1.9 currents contribute to pain following peripheral inflammation. (D) Behavioral response of WT, Nav1.9 +/-, and Nav1.9-/- mice following spared nerve injury. The nerve injury produced a reduction of mechanical threshold (von Frey) that was similar in all three genotypes, indicating that Nav1.9 currents do not play a major role in neuropathic pain associated with nerve injury. C and D modified with permission from Amaya et al., 2006. (C) 2006 by the Society for Neuroscience. 

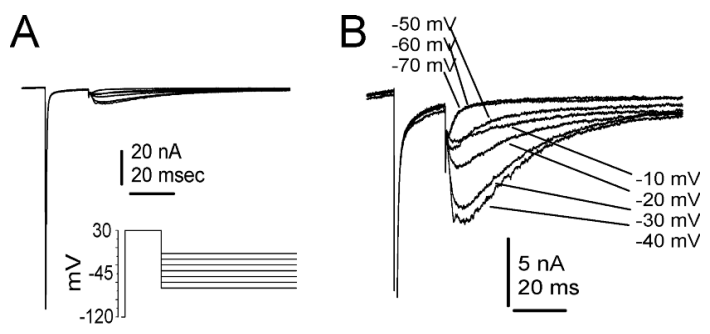

Figure 6.

TTX-sensitive resurgent currents are detected in some DRG sensory neurons. (A) Representative resurgent sodium currents recorded from a large (64 pF) sensory neuron. The voltage protocol used to elicit the currents is shown in inset. (B) The amplitudes of the traces in (A) are magnified in order to better see the resurgent currents. Adapted from Cummins et al., 2005. (C) 2005 Elsevier. 